\title{
ACTIVE CONSTITUENTS AND BIOLOGICAL ACTIVITY OF METHANOLIC EXTRACT OF FORSSKAOLEA VIRIDIS AERIAL PARTS
}

\author{
FATMA ALY AHMED, TAHA A. I. EL-BASSOSSY*
}

\author{
Department of Medicinal and Aromatic Plants, Desert Research Center, Cairo, Egypt. Email: tahachemist2008@gmail.com
}

Received: 27 November 2019, Revised and Accepted: 01 January 2020

\begin{abstract}
Objective: The objective of this study is to isolate and evaluate the antioxidant, antimicrobial, and antitumor activity of the methanolic constituents of Forsskaolea viridis.

Methods: The isolation and purification of phytochemical constituents were performed in the present study using various chromatographic methods (thin-layer [TLC], preparative paper [PPC], and column chromatography [CC]) where, the structures of isolated compounds were determined using different spectroscopic methods (Mass spectroscopy [Ms], ultraviolet [UV], proton and carbon nuclear magnetic resonance [ ${ }^{1} \mathrm{H}-\mathrm{NMR}$ and $\left.{ }^{13} \mathrm{C}-\mathrm{NMR}\right]$ ) and confirmed by data reported in the literature. The biological activity of the methanolic extract was performed as in vitro studies by diffusion agar technique, 2,2-Diphenyl-1-picrylhydrazyl hydrate (DPPH), and 3-(4,5-Dimethylthiazol-2-yl)-2,5-diphenyltetrazolium bromide (MTT) assay for antimicrobial, antioxidant, and antitumor activity, respectively.
\end{abstract}

Results: The chemical studies led to the isolation of five flavonoids and two phenolic compounds for the first time from this plant. The methanolic extract exhibited potent antimicrobial activity $(13-26 \mathrm{~mm})$ against some of the tested strains while it showed fair antioxidant and cytotoxicity activity.

Conclusion: It can be concluded from the results that the methanolic extract of $F$. viridis has potential antimicrobial activity while fair antioxidant and antitumor activity.

Keywords: Forsskaolea viridis, Phenolics, Flavonoids, Antimicrobial, Antioxidant, Antitumor.

(C) 2020 The Authors. Published by Innovare Academic Sciences Pvt Ltd. This is an open access article under the CC BY license (http://creativecommons. org/licenses/by/4. 0/) DOI: http://dx.doi.org/10.22159/ajpcr.2020.v13i3.36503

\section{INTRODUCTION}

Ever since ancient times, humans were looking for drugs to rescue their disease. At this time, there is no medicinal source help them in the treatment of their diseases other than medicinal plants which provided humankind with herbal remedies for several diseases for many centuries. Therefore, human beings tended to use therapeutic plants to treat many diseases where medicinal plants proved effective in treating diseases because they contain many active materials, proteins, vitamins, hormones, ...etc. Family Urticaceae comprises 54 genera and more than 2000 species of herbs, shrubs, small trees, and a few vines [1]. Forsskaolea is a small genus in the Urticaceae family, represented by six species, distributed in Canary Isles and Southeast Spain eastwards to Pakistan, Africa, and Arabia to West India [2]. Reported activities for the Forsskaolea genus are diuretic, calculolitic, antiflu [3], and antiseptic [4]. Forsskaolea viridis Ehrenb. ex Webb is an annual or short-lived perennial herb distributed in Egypt (Southeast Egypt - Wadi Kansisrob), Oman (Dhofar), Saudi Arabia, Yemen (Hadhramaut), Namibia, Sudan, Ethiopia, Eritrea, and Kenya [5]. The survey on the previous studies on the F. viridis plant showed no chemical and biological studies performed on it so; we aimed to investigate the active chemical constituents of its different extracts in addition to their biological activity [6]. In this study, we concerned to focus our study on the methanolic extract of $F$. viridis aerial parts and its biological activity of $F$. viridis aerial parts.

\section{METHODS}

\section{Plant material}

Aerial parts of $F$. viridis were collected from their natural habitat in Wadi Kansisrob, Gebel Elba region, Southeast corner of Egypt in January 2016. The plant specimens were identified, authenticated, and deposited in the herbarium of Desert Research Center (CAIH) with Code Number: CAIH-1000-R.

\section{Chemicals}

All chemicals used were of high quality and analytical grade purchased from Sigma-Aldrich.

\section{Chemical studies}

Extraction

About $1.5 \mathrm{~kg}$ of the air-dried powder of $F$. viridis aerial parts extracted by successive extraction by Soxhlet apparatus starting with petroleum ether to remove the lipoidal matters with increasing polarity then, filtered off, the marc lifted was re-extracted by the same way (this process repeated several times). The same combined extracts for each solvent were concentrated separately under reduced pressure at a temperature not exceeding $50^{\circ} \mathrm{C}$ till dryness. The petroleum ether, chloroform, ethyl acetate, $100 \%$ methanol, $50 \%$ methanol, and water were used [6]. The same combined extracts for each solvent were concentrated separately under reduced pressure at a temperature not exceeding $50^{\circ} \mathrm{C}$ till dryness.

\section{Isolation}

The aqueous methanolic extract (130 g) was dissolved in a little amount of water, treated with an excess of methanol and filtered to remove inorganic salts and non-phenolic compounds. The residual extract after removal of inorganic salts was extracted with increasing polarity according to scheme (Fig. 1) as $100 \% \mathrm{MeOH}, 50 \% \mathrm{MeOH}$, and finally $100 \%$ water, then subjected to paper chromatography using butanol:acetic acid:water (BAW) upper layer (4:1:5) and 15\% acetic acid:water $(15 \% \mathrm{AcOH})$ which revealed similarity of two fractions $100 \% \mathrm{MeOH}$ and $50 \% \mathrm{MeOH}$, so they were collected together and subjected to polyamide column starting with water with decreasing polarity to $100 \% \mathrm{MeOH}$ afforded 22 fractions (M1-M22), each fraction was $250 \mathrm{ml}$. Similar fractions were collected together which finally give five main fractions that needed to further isolation on polyamide 
Table 1: Column fractions of methanolic extract of Forsskaolea viridis aerial parts

\begin{tabular}{llll}
\hline Fraction No. & Solvent system & Pooled fractions & Weight (g) \\
\hline I & $\mathrm{H}_{2} \mathrm{O}$ & $1-2$ & 51.0 \\
II & $\mathrm{MeOH}: \mathrm{H}_{2} \mathrm{O}(20: 100)$ & $3-10$ & 4.3 \\
III & $\mathrm{MeOH}: \mathrm{H}_{2} \mathrm{O}(40: 100)$ & $11-12$ & 0.8 \\
IV & $\mathrm{MeOH}: \mathrm{H}_{2} \mathrm{O}(60: 100)$ & $13-18$ & 4.0 \\
V & $\mathrm{MeOH}: \mathrm{H}_{2} \mathrm{O}(90: 100)$ & $19-22$ & 1.7 \\
\hline
\end{tabular}

column, preparative paper, and thin-layer chromatography, then applied to Sephadex LH-20 column for final purification of isolated compounds.

Methanolic extract (55 g dissolved in $50 \mathrm{ml}$ aqueous methanol 3:1) over polyamide crude $(250 \mathrm{~g})$ column $(150 \mathrm{~cm} \times 5 \mathrm{~cm})$ and elution with methanol/bi-distilled water mixture of decreasing polarities for gradient elution led to the desorption of five individual fractions (I-V) which were dried individually, in vacuum, and then subjected to twodimensional paper chromatographic investigation.

\section{Biological studies}

Antimicrobial activity

Antimicrobial activity was determined by the diffusion agar technique in Regional Center for Mycology and Biotechnology Al-Azhar University, Cairo, Egypt (RCMB), according to CLSI $[7,8]$. Strains were obtained from the bacteria stock present at RCMB. Petri plates containing $20 \mathrm{ml}$ of nutrient (for bacteria) or malt extract (for fungi), agar medium were seeded with 1-3 days cultures of microbial inoculums (standardized inoculums $1-2 \times 10^{7} \mathrm{cfu} / \mathrm{ml} 0.5$ McFarland standard). Wells (6 mm in diameter) were cut off into agar and $100 \mu \mathrm{l}$ of plant extracts were tested in a concentration of $5 \mathrm{mg} / \mathrm{ml}$ and incubated at $37^{\circ} \mathrm{C}$ for $24 \mathrm{~h}$ (bacterial strains) and $25^{\circ} \mathrm{C}$ for 7 days (fungal strains). The assessment of antimicrobial activity was based on the measurement of the diameter of the inhibition zone formed around the well. The positive control used for fungi was ketoconazole with minimum inhibitory concentration (MIC) $100 \mathrm{mg} / \mathrm{ml}$, while positive control used for bacteria strains was gentamycin with MIC $4 \mathrm{mg} / \mathrm{ml}$.

Antioxidant activity (2,2-diphenyl-1-picrylhydrazyl hydrate [DPPH] assay) The free radical scavenging effect of plant extract was assessed by the decoloration solution of DPPH radical, as described in Letelier et al. [9]. This assay was realized essentially by the method reported in Joyeux et al. [10] and its modification [11]. In a final volume of $1 \mathrm{ml}$, the reaction mixture contained $20 \mu \mathrm{g} / \mathrm{ml}$ of DPPH (ethanol solution) and different concentrations of methanol extract. Blanks contained only ethanol and plant extract. DPPH bleaching activity of all mixtures was measured continuously at $37^{\circ} \mathrm{C}$ for $20 \mathrm{~min}-517 \mathrm{~nm}$ in a ultraviolet (UV3) Unicam UV-visible spectrophotometer. Reaction rates were determined at conditions where product formation was linearly dependent on time and protein concentration. DPPH bleaching activity was expressed as $\Delta$ Absorbance/20 min, which corresponds to the difference between the initial ( $0 \mathrm{~min}$ ) and final absorbance (20 min). Ascorbic acid was used as positive control.

\section{Cytotoxic activity (viability assay)}

The human breast (MCF-7), colon (Caco-2), and hepatic (HepG-2) carcinoma cell lines were obtained in the frozen state under liquid nitrogen $\left(-180^{\circ} \mathrm{C}\right)$ from the American type culture collection. The tumor cell lines were maintained by serial subculturing in the National Cancer Institute, Cairo, Egypt. The cytotoxic effect of methanol extract was evaluated in the National Cancer Institute, according to the 3-(4,5-Dimethylthiazol-2-yl)-2,5-diphenyltetrazolium bromide (MTT) assay method [12]. Briefly, cells were seeded in 96 well plates at a density of 5000 cells/well in $100 \mu$ culture medium. Following $24 \mathrm{~h}$ incubation, cells were treated with various concentrations of methanol extract and then incubated for $24 \mathrm{~h}$ at $37^{\circ} \mathrm{C}$ with $5 \% \mathrm{CO}_{2}$. After incubation, the medium was replaced with $100 \mu \mathrm{l}$ of MTT solution prepared fresh as
$0.5 \mathrm{mg} / \mathrm{ml}$ in Dulbecco's Modified Eagle Medium, filtered through a $0.22 \mu \mathrm{m}$ filter, was added to each well, and the plates were incubated in the dark for $4 \mathrm{~h}$ at $37^{\circ} \mathrm{C}$. Then, the media were removed and $200 \mu \mathrm{l}$ of dimethyl sulfoxide (DMSO) was added to each well and absorbance was measured at $570 \mathrm{~nm}$ using a microplate reader. The results are expressed as the percentage of cell viability in comparison with the control cells (cells without extract). The cell viability of the control group without exposure to the extracts was defined as $100 \%$.

\section{Statistical analysis}

Biological experimental results are presented as means scanning electron microscope, and all measurements and analyses were carried out in triplicate. SPSS statistical software was used. Statistical analysis was performed by one-way analysis of variance.

\section{RESULTS AND DISCUSSION}

\section{Chemical studies}

The isolation of active chemical constituents of the methanolic extract of $F$. viridis aerial parts was performed according to the scheme Fig. 1. The identification and structure elucidation of the purified phenolic and flavonoid compounds were done by comparison, $\mathrm{R}_{\mathrm{f}}$ values, $\mathrm{UV}$, ${ }^{1} \mathrm{H}$-nuclear magnetic resonance (NMR), ${ }^{13} \mathrm{C}$-NMR spectral data with the reported data in the literature.

Compound (1) appeared as a dark purple spot under UV light turning orange when fumed with ammonia, which exhibited a $M r$ of 610 in electrospray ionization mass spectrometry (ESI-MS) analysis $\left([\mathrm{M}+\mathrm{H}]{ }^{-}\right.$at $m / z=611), \mathrm{R}_{\mathrm{f}} 0.43$ (BAW), 0.57 (6\% AcOH). UV $\lambda_{\max }(\mathrm{nm}): \mathrm{MeOH}: 258$, 264, 295, 357; (NaOMe) 271, 325, 408; (NaOAc) 270, 324, 392; (NaOAc/ $\left.\mathrm{H}_{3} \mathrm{BO}_{3}\right)$ 260, 296, 385; $\left(\mathrm{AlCl}_{3}\right) 275,303,433$; $\left(\mathrm{AlCl}_{3} / \mathrm{HCl}\right) 271,299,364$, 402. ${ }^{1} \mathrm{H}-\mathrm{NMR}$ (DMSO-d6): Quercetin moiety: $\delta 7.75(1 \mathrm{H}, \mathrm{d}, J=2.5 \mathrm{~Hz}$, $\left.\mathrm{H}-2^{\prime}\right), 7.58\left(1 \mathrm{H}, \mathrm{dd}, J=2.5\right.$ and $\left.8 \mathrm{~Hz}, \mathrm{H}-6^{\prime}\right), 6.93\left(1 \mathrm{H}, \mathrm{d}, J=8 \mathrm{~Hz}, \mathrm{H}-5^{\prime}\right)$, $6.85\left(1 \mathrm{H}, \mathrm{d}, J=8 \mathrm{~Hz}, \mathrm{H}-5^{\prime}\right), 6.43(1 \mathrm{H}, \mathrm{d}, J=2.5 \mathrm{~Hz}, \mathrm{H}-8), 6.22(1 \mathrm{H}, \mathrm{d}, J=2.5 \mathrm{~Hz}$, H-6). Glucose moiety: $\delta 5.14\left(1 \mathrm{H}, \mathrm{d}, J=8.5 \mathrm{~Hz}, \mathrm{H}-1^{\prime \prime}\right), 3.15-3.85(5 \mathrm{H}, m)$. Rhamnose moiety: $\delta 4.51\left(1 \mathrm{H}, \mathrm{d}, J=2.5 \mathrm{~Hz}, \mathrm{H}-1^{\prime \prime \prime}\right), 3.2-3.85(5 \mathrm{H}, m)$, $1.12\left(3 \mathrm{H}, \mathrm{d}, J=6.5 \mathrm{~Hz}, \mathrm{CH}_{3}\right.$ rhamnose). ${ }^{13} \mathrm{C}-\mathrm{NMR}$ (DMSO-d6): Quercetin moiety: $\delta 179.4$ (C-4), 165.1 (C-7), 162.1 (C-9), 158.5 (C-5), 157.1 (C-2), 148.5 (C-4'), 145.6 (C-3'), 135.1 (C-3), 123.1 (C-6'), 121.5 (C-1'), 117.2 (C-5'), 115.8 (C-2'), 104.8 (C-10), 97.5 (C-6), 94.5 (C-8). Glucose moiety: $\delta 102.4$ (C-1"), 79.3 (C-3"), 77.5 (C-5"), 73.9 (C-2"), 72.4 (C-4"), 66.9 (C6"). Rhamnose moiety: $\delta 100.4$ (C-1'”), 73.4 (C-4'”), 71.2 (C-3'”), 70.7 (C-2'”), 69.1 (C-5'”), 18.6 ( $\mathrm{CH}_{3}$-rhamnose). Compound (1) was identified as rutin. The spectroscopic data of compound (1) were similar to the physical and spectral data recorded in Wei et al. [13].

Compound (2) was purely isolated as deep purple spot under UV light turning yellowish green when fumed with ammonia, which exhibited a $M r$ of 610 in ESI-MS analysis $\left([\mathrm{M}+\mathrm{H}]^{-}\right.$at $\left.m / z=611\right), \mathrm{R}_{\mathrm{f}} 0.14$ (BAW), 0.39 (15\% AcOH). UV $\lambda_{\max }(\mathrm{nm}): \mathrm{MeOH}: 256,274,345$; (NaOMe) 268, 282, 342, 413; (NaOAc) 269, 283, 327, 407; ( $\mathrm{NaOAc} / \mathrm{H}_{3} \mathrm{BO}_{3}$ ) 277, 285, 362, 425; $\left(\mathrm{AlCl}_{3}\right)$ 279, 303, 332, 402; $\left(\mathrm{AlCl}_{3} / \mathrm{HCl}\right) 261,278,295,354$, 386. ${ }^{1} \mathrm{H}-\mathrm{NMR}$ (DMSO-d6): Aglycone moiety: $\delta 7.57(1 \mathrm{H}, \mathrm{dd}, J=8.5 \mathrm{~Hz}$, $\left.2.5 \mathrm{~Hz}, \mathrm{H}-6^{\prime}\right), 7.39\left(1 \mathrm{H}, \mathrm{d}, J=2.0 \mathrm{~Hz}, \mathrm{H}-2^{\prime}\right), 6.88\left(1 \mathrm{H}, \mathrm{d}, J=8.5 \mathrm{~Hz}, \mathrm{H}-5^{\prime}\right)$, $6.46(1 \mathrm{H}, \mathrm{s}, \mathrm{H}-3)$. Glucose moiety at position $6: \delta 4.72(1 \mathrm{H}, \mathrm{d}, J=9.8 \mathrm{~Hz}$, $\mathrm{H}-1$ ) $)$, 3.21-3.89 (5H, m sugar protons) glucose moiety at position 8: $\delta 4.95\left(1 \mathrm{H}, \mathrm{d}, J=8.6 \mathrm{~Hz}, \mathrm{H}-1^{\cdots}\right), 3.21-3.89$ (5H, m, overlapped protons). ${ }^{13} \mathrm{C}-\mathrm{NMR}$ (DMSO-d6): $\delta 181.62$ (C-4), 166.22 (C-2), 163.61 (C-7), 159.3 (C-5), 156.93 (C-9), 150.21 (C-4'), 147.54 (C-3'), 132.51 (C-1'), 129.16 (C-2', C-6'), 116.20 (C-5') 109.92 (C-6), 105.63 (C-8), 103.95 (C-10), 103.31 (C-3). Sugar moieties: $\delta 81.18$ (C-5", C-5"'"-overlapped), 78.81 (C-3", C-3"'-overlapped), 73.32 (C-1", C-1"'- overlapped), 70.21 (C-2", C-2"'-overlapped), 70.83 (C-4", C-4"'-overlapped), 60.6 (C-6", C-6"'-overlapped). Compound (2) was identified as lucenin-2. The spectroscopic data of compound (2) were harmony with those data recorded in Erel et al. [14].

Compound (3) was purely isolated as colorless needle crystals, appeared on PC as blue spot under UV light turning to intense blue when fumed with ammonia, it was found to exhibit $\mathrm{Mr}$ of 354 in ESI-MS analysis 


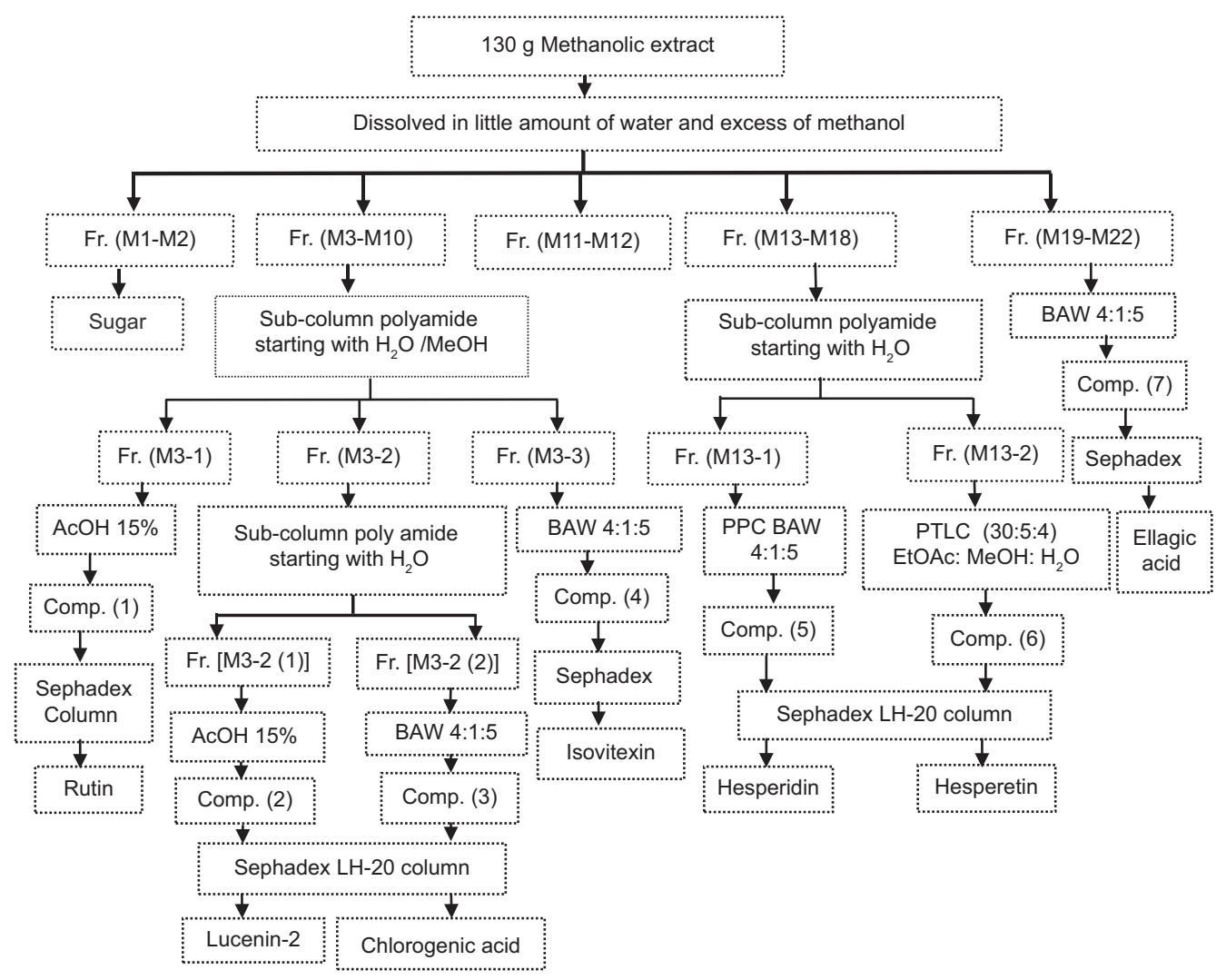

Fig. 1: Isolation scheme of isolated compounds from Forsskaolea viridis methanolic extract<smiles>[R]c1c(O)c([R1])c2oc(-c3ccc(O)c(O)c3)c([R])c(=O)c2c1O</smiles>

$1 \mathrm{R}=$ O-Rutinoside, $\mathrm{R}^{1}=\mathrm{R}^{2}=\mathrm{H}$

$2 \mathrm{R}=\mathrm{H}, \mathrm{R}^{1}=\mathrm{R}^{2}=$ Glucose

$4 \mathrm{R}=\mathrm{O}$ - Rhamnose, $\mathrm{R}^{1}=\mathrm{R}^{2}=\mathrm{H}$,<smiles>[R9]Oc1cc(O)c2c(c1)OC(c1ccc(OC)c(O)c1)CC2=O</smiles><smiles>O=C(/C=C/c1ccccc1)OC1C[C@](O)(C(=O)O)C[C@H](O)[C@H]1O</smiles>

3<smiles>O=c1oc2c(O)c(O)cc3c(=O)oc4c(O)c(O)cc1c4c23</smiles>

Fig. 2: Chemical structures of the isolated compounds from Forsskaolea viridis methanolic extract

$\left([\mathrm{M}+\mathrm{H}]^{+}\right.$at $\left.m / z=455\right), \mathrm{R}_{\mathrm{f}} 0.60$ (BAW), 0.54 (HOAC-15\%).UV $\lambda_{\max }(\mathrm{nm}):$ MeOH: 278. ${ }^{1} \mathrm{H}-\mathrm{NMR}$ (DMSO-d6): Quinic acid moiety: $\delta 5.16(1 \mathrm{H}, \mathrm{br} \mathrm{d}$, $J=5 \mathrm{~Hz}, \mathrm{H}-3), 3.92(1 \mathrm{H}, \mathrm{br} \mathrm{s}, \mathrm{H}-5), 3.5(1 \mathrm{H}, \mathrm{br} \mathrm{d}, J=5 \mathrm{~Hz}, \mathrm{H}-4), 1.97(2 \mathrm{H}$, br d, $J=5 \mathrm{~Hz}, \mathrm{H}-2), 1.7-2.2(2 \mathrm{H}, m, \mathrm{H}-6)$. Caffeoyl moiety: $\delta 7.72(1 \mathrm{H}, \mathrm{d}$, $\left.J=15, \mathrm{H}-7^{\prime}\right), 7.35\left(1 \mathrm{H}\right.$, broad s, H-2'), $7.03\left(1 \mathrm{H}, \mathrm{dd}, J=2.3\right.$, and $\left.J=8.5, \mathrm{H}-6^{\prime}\right)$, $6.77\left(1 \mathrm{H}, \mathrm{d}, J=8.5, \mathrm{H}-5^{\prime}\right), 6.16$ (1H, d, J=15, H-8'). ${ }^{13} \mathrm{C}-\mathrm{NMR}$ (DMSO-d6): Quinic acid moiety: $\delta 177.4$ (C=0), 73.4 (C-4), 71.31 (C-1), 71.33 (C-3), 68.2 (C-5), 39.4 (C-2), 39.5 (C-6). Caffeoyl moiety: $\delta 199.9$ (C-9'), 148.6 (C-3'), 146.0 (C-4'), 144.9 (C-7'), 126.1 (C-1' and C-6'), 121.6 (C-5'), 115.5 (C-8'), 115.1(C-2'). Compound (3) was identified as chlorogenic acid. The spectroscopic data of compound (3) were identical with those data recorded in Berregi et al. and Lee et al. $[15,16]$.

Compound (4) was purely isolated as yellow powder from Fraction II, deep purple spot under UV light turning yellowish green when fumed with ammonia, it was found to exhibit $M r$ of 432 in ESI-MS analysis $\left([\mathrm{M}+\mathrm{H}]^{+}\right.$at $\left.m / z=433\right), \mathrm{R}_{\mathrm{f}} 0.56$ (BAW), $0.54(15 \% \mathrm{AcOH}) . \mathrm{UV} \lambda_{\max }(\mathrm{nm}):$ MeOH: 273, 330; (NaOMe): 277, 331, 394; (NaOAc): 279, 389; (NaOAc/ $\left.\mathrm{H}_{3} \mathrm{BO}_{3}\right): 271,319,346 ;\left(\mathrm{AlCl}_{3}\right): 266,301,348,370 ;\left(\mathrm{AlCl}_{3} / \mathrm{HCl}\right): 262$, 303, 343, 381. ${ }^{1} \mathrm{H}-\mathrm{NMR}$ (DMSO-d6): Apigenin moiety: $\delta 7.79(2 \mathrm{H}, \mathrm{d}$, $J=8.6 \mathrm{~Hz}, \mathrm{H}-2^{\prime}$ and $\left.\mathrm{H}-6^{\prime}\right), 6.93\left(2 \mathrm{H}, \mathrm{d}, J=8.7 \mathrm{~Hz}, \mathrm{H}-3^{\prime}\right.$ and $\left.\mathrm{H}-5^{\prime}\right), 6.72(1 \mathrm{H}, \mathrm{s}$, $\mathrm{H}-3), 6.49(1 \mathrm{H}, \mathrm{d}, J=2.0 \mathrm{~Hz}, \mathrm{H}-8)$. Glucose moiety: $\delta 4.89(1 \mathrm{H}, \mathrm{d}, J=9.2 \mathrm{~Hz}$, H-1"), 3.2-3.74 (5H, m) ${ }^{13} \mathrm{C}$-NMR (DMSO-d6): Apigenin moiety: $\delta$ 181.59 (C-4), 164.68 (C-2), 163.33 (C-7), 161.30 (C-4'), 157.24 (C-5), 152.28 (C-9), 128.34 (C-6'), 127.21 (C-2'), 122.26 (C-1'), 116.18 (C-5'), 114.88 (C-3'), 109.70 (C-6), 104.33 (C-3), 103.40 (C-10), 94.19 (C-8). Glucose moiety: $\delta 83.12$ (C-5"), 79.69 (C-3"), 74.09 (C-1"), 72.18 (C-2"), 71.28 (C-4"), 61.88 (C-6"). Compound (4) was identified as isovitexin. The spectroscopic data of compound (4) were similar with those data reported in Mabry et al. and Luzzatto et al. $[17,18]$. 
Compound (5) was purely isolated as a pale yellow amorphous powder from Fraction IV, appeared as a dark purple spot on PC under UV light turning to blue when fumed with $\mathrm{NH}_{3}$ vapor, it was found to exhibit $M r$ of 610 in ESI-MS analysis $([\mathrm{M}+\mathrm{H}]$ ' at $m / z=611.1) . \mathrm{R}_{\mathrm{f}} 0.54$ (BAW),

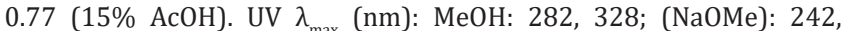
288, 356; (NaOAc): 286, 329; ( $\left.\mathrm{NaOAc} / \mathrm{H}_{3} \mathrm{BO}_{3}\right)$ : 284, 327; $\left(\mathrm{AlCl}_{3}\right)$ : 308, 384; $\left(\mathrm{AlCl}_{3} / \mathrm{HCl}\right): 305,380 .{ }^{1} \mathrm{H}-\mathrm{NMR}$ (DMSO-d6): Hesperetin moiety: $\delta$ $7.01\left(1 \mathrm{H}, \mathrm{d}, J=2.3 \mathrm{~Hz}, \mathrm{H}-2^{\prime}\right), 6.85\left(1 \mathrm{H}, \mathrm{dd}, J=8.5,2.3 \mathrm{~Hz}, \mathrm{H}-6^{\prime}\right), 6.78(1 \mathrm{H}$, d, J=8.5 Hz, H-5'), $6.02(1 \mathrm{H}, \mathrm{s}, \mathrm{H}-8), 5.82(1 \mathrm{H}, \mathrm{s}, \mathrm{H}-6), 5.53(1 \mathrm{H}, \mathrm{dd}$, $J=12.0,2.4 \mathrm{~Hz}, \mathrm{H}-2), 3.89\left(3 \mathrm{H}, \mathrm{s}, 4^{\prime}-\mathrm{OCH}_{3}\right), 3.17(1 \mathrm{H}, \mathrm{dd}, J=13.0,5.0 \mathrm{~Hz}$, H-3 eq.), 2.78 (1H, dd, J=13.0, $5.0 \mathrm{~Hz}, \mathrm{H}-3$ ax.). Sugar moiety: $\delta 5.12(1 \mathrm{H}$, d, $\left.J=7.2 \mathrm{~Hz}, \mathrm{H}-1^{\prime \prime}\right), 4.51\left(1 \mathrm{H}, \mathrm{d}, J=9.2 \mathrm{~Hz} ; \mathrm{H}-1^{\prime \prime \prime}\right), 1.09(3 \mathrm{H}, \mathrm{d}, J=6.0 \mathrm{~Hz}$, H-6"'), 3.2-3.74 (5H, m, overlapped protons). ${ }^{13} \mathrm{C}-\mathrm{NMR}$ (DMSO-d6): Hesperetin moiety: $\delta 182.4$ (C-4), 166.5 (C-7), 164.4 (C-5), 161.3 (C-9), 146.2 (C-4'), 144.7 (C-3'), 132.4 (C-1'), 120.0 (C-6'), 116.8 (C-2'), 111.2 (C-5'), 103.4 (C-10), 96.5 (C-6), 94.5 (C-8), 77.7 (C-2), $51.3\left(\mathrm{OCH}_{3}\right)$, 43.2 (C-3). Glucose moiety: $\delta 102.4$ (C-1"), 79.3 (C-3"), 77.5 (C-5"), 73.9 (C-2"), 72.4 (C-4"), 66.9 (C-6"). Rhamnose moiety: $\delta 98.7$ (C-1"), 73.3 (C-4"'), 71.0 (C-3'”), 70.5 (C-2'"), 68.1 (C-5'”), 19.1(C-6'" rhamnose). Compound (5) was identified as hesperidin. The spectroscopic data of compound (5) were similar to the reported data outlined by Mabry et al. and Han et al. $[17,19]$.

Compound (6) was purely isolated as a pale yellow powder from Fraction IV, appeared as a dark purple spot on PC under UV light turning to blue when fumed with $\mathrm{NH}_{3}$ vapor, it was found to exhibit of $\mathrm{Mr} 302$ in ESI-MS analysis $([\mathrm{M}+\mathrm{H}]$ ' at $m / z=303)$. $\mathrm{R}_{\mathrm{f}} 0.54$ (BAW), $0.77(15 \% \mathrm{AcOH})$. UV $\lambda_{\max }$ (nm): MeOH: 287, 335; (NaOMe): 240, 284, 350; (NaOAc): 285, 330; $\left(\mathrm{NaOAc} / \mathrm{H}_{3} \mathrm{BO}_{3}\right)$ : 284, 327; $\left(\mathrm{AlCl}_{3}\right)$ ): 308, 384; $\left(\mathrm{AlCl}_{3} / \mathrm{HCl}\right): 300,340$. ${ }^{1} \mathrm{H}-\mathrm{NMR}$ (DMSO-d6): $\delta 7.01\left(1 \mathrm{H}, \mathrm{d}, J=2.3 \mathrm{~Hz}, \mathrm{H}-2^{\prime}\right), 6.85$ (1H, dd, $J=8.5$, $\left.2.3 \mathrm{~Hz}, \mathrm{H}-6^{\prime}\right), 6.78\left(1 \mathrm{H}, \mathrm{d}, J=8.5 \mathrm{~Hz}, \mathrm{H}-5^{\prime}\right), 6.02(1 \mathrm{H}, \mathrm{s}, \mathrm{H}-8), 5.82(1 \mathrm{H}, \mathrm{s}$, $\mathrm{H}-6), 5.53(1 \mathrm{H}, \mathrm{dd}, J=12.0,2.4 \mathrm{~Hz}, \mathrm{H}-2), 3.89\left(3 \mathrm{H}, \mathrm{s}, 4^{\prime}-\mathrm{OCH}_{3}\right), 3.17(1 \mathrm{H}$, $\mathrm{dd}, J=13.0,5.0 \mathrm{~Hz}, \mathrm{H}-3$ eq.), $2.78(1 \mathrm{H}, \mathrm{dd}, J=13.0,5.0 \mathrm{~Hz}, \mathrm{H}-3 \mathrm{ax}.){ }^{13} \mathrm{C}-\mathrm{NMR}$ (DMSO-d6): $\delta 182.4$ (C-4), 166.5 (C-7), 164.4 (C-5), 161.3 (C-9), 146.2 (C-4'), $144.7\left(\mathrm{C}-3^{\prime}\right), 132.4\left(\mathrm{C}-1^{\prime}\right), 120.2\left(\mathrm{C}-6^{\prime}\right), 116.8\left(\mathrm{C}-2^{\prime}\right), 111.2\left(\mathrm{C}-5^{\prime}\right)$, 103.4 (C-10), 96.5 (C-6), 94.5 (C-8),77.7 (C-2), $51.3\left(\mathrm{OCH}_{3}\right), 43.2$ (C-3). Compound (6) was identified as hesperetin. The spectroscopic data of compound (6) were similar to the reported data outlined by Mabry et al. and Han et al. $[17,19]$.

Compound (7) was purely isolated as a faint yellow needles from Fraction V, appeared as a blue spot on PC under UV light turning to intense blue when fumed with $\mathrm{NH}_{3}$ vapor, it was found to exhibit of $\mathrm{Mr}$ 302 in its negative ESI-MS analysis $([\mathrm{M}-\mathrm{H}]$ at $m / z=301) . \mathrm{R}_{\mathrm{f}} 48$ (BAW) 09 (15\% HOAc). UV $\lambda_{\text {max }}(\mathrm{nm})$ : MeOH: 255, 362. ${ }^{1} \mathrm{H}-\mathrm{NMR}$ (DMSO-d6): 7.48 (s, H-5 and, H-5'). Compound (7) was identified as ellagic acid. The spectroscopic data of compound (7) were typical to the reported data outlined in Nawwar et al. [20].

\section{Biological studies}

Antimicrobial activity

The inefficacy of currently available antibiotics urges the searching for new type antibacterial agents against the drug-resistant bacteria. Since the pharmaceutical development has historically relied on natural products to provide biological active compounds, screening for natural antibacterial agents have been broadly studied, and even become new leads for antibacterial drug discovery $[21,22]$. The antibacterial and antifungal activities of the methanolic extract of $F$. viridis were carried out by diffusion agar technique. Mean zone of inhibition in millimeter produced on a range of pathogenic microorganisms was measured and the results are recorded in Table 2. The maximum inhibitory responses were indicated after the treatment of all tested bacteria and fungi strain with the concentration of $5 \mathrm{mg} / \mathrm{ml}$ of the methanol extract, where the methanolic extract showed potent antimicrobial activity about $(62-86 \%)$ for the most of tested organisms compared to gentamicin and ketoconazole. The maximum response of Grampositive bacteria was methicillin-resistant Staphylococcus aureus with inhibition zone $13 \mathrm{~mm}$ with activity $86.6 \%$ near to the gentamycin control and Micrococcus sp. with inhibition zone $18 \mathrm{~mm}$ with activity
81.8\% when compared to inhibition zone of gentamicin as a reference drug. This refers to the methanolic phytochemical constituents of the methanolic extract recommended to treat some of the respiratory tract infections such as coughing, sneezing and lungs, throat inflammatory or through contact with infected wounds or sores, or during vaginal delivery (from mother to child) [23]. The maximum response of Gramnegative bacteria was both Escherichia coli and Klebsiella pneumoniae with inhibition zone $26 \mathrm{~mm}$ and $14 \mathrm{~mm}$ with activity 86.6 and $66.6 \%$, respectively, according to gentamicin control. On the other hand, the maximum inhibitory zone of yeasts and filamentous fungi was Cryptococcus neoformans with inhibition zone $19 \mathrm{~mm}$ with activity about $76 \%$ for yeast fungi while the filamentous fungi were Aspergillus fumigatus with inhibition zone $12 \mathrm{~mm}$ with activity $70.5 \%$ when compared of inhibition zone of ketoconazole as a reference drug.

The relatively high inhibition and the activity of the methanol extract against most of the bacteria and fungi strains may be due to their contents from phenolic and flavonoid compounds and other bioactive metabolites [24], which causes damage to the cell membrane of bacteria and fungi leading to the inhibition of macromolecular synthesis, depolarization of membrane, and inhibition of DNA, RNA, and proteins synthesis of microbe which effect on its growth than its death [25]. The reason for the antimicrobial activity of isolated phenolic and flavonoid compounds may be due to their skeleton structures that possess hydroxyl groups at special sites on the aromatic ring that increase its activity. Furthermore, the hydrophobic substituents such as prenyl groups, alkyl chains, and oxygen-containing heterocyclic moieties usually enhance the activity for all the flavonoids. Hence, the antibacterial mechanisms of isolated compounds are as follows: Inhibition of nucleic acid synthesis, inhibition of cytoplasmic membrane

Table 2: The antimicrobial activity of the methanolic extract of Forsskaolea viridis aerial parts against different bacterial and fungal strains

\begin{tabular}{|c|c|c|}
\hline \multirow[t]{2}{*}{ Tested organism } & \multicolumn{2}{|c|}{$\begin{array}{l}\text { Inhibition zone } \\
\text { diameter }(\mathrm{mm})\end{array}$} \\
\hline & Control** $^{* *}$ & MeOH extract \\
\hline Gram-positive bacteria & \multicolumn{2}{|c|}{ Gentamycin $(4 \mathrm{mg} / \mathrm{ml})$} \\
\hline Micrococcus sp. (RCMB 028) & $22 \pm 0.12$ & $18 \pm 0.04$ \\
\hline $\begin{array}{l}\text { Streptococcus mutants (RCMB 017) } \\
\text { (ATCC } 25175 \text { ) }\end{array}$ & $21 \pm 0.14$ & $13 \pm 0.19$ \\
\hline $\begin{array}{l}\text { Methicillin-resistant } \\
\text { Staphylococcus aureus }\end{array}$ & $15 \pm 0.13$ & $13 \pm 0.11$ \\
\hline
\end{tabular}

\begin{tabular}{|c|c|c|}
\hline Gram-negative bacteria & \multicolumn{2}{|c|}{ Gentamycin $(4 \mathrm{mg} / \mathrm{ml})$} \\
\hline $\begin{array}{l}\text { Salmonella typhimurium (RCMB 006) } \\
\text { (ATCC 14028) }\end{array}$ & $17 \pm 0.09$ & $13 \pm 0.11$ \\
\hline $\begin{array}{l}\text { Escherichia coli (RCMB 010052) } \\
\text { (ATCC 25955) }\end{array}$ & $30 \pm 0.11$ & $26 \pm 0.21$ \\
\hline $\begin{array}{l}\text { Klebsiella pneumoniae (RCMB 003) } \\
\text { (ATCC 13883) }\end{array}$ & $21 \pm 0.23$ & $14 \pm 0.06$ \\
\hline Filamentous fungi & \multicolumn{2}{|c|}{ Ketoconazole $(100 \mathrm{mg} / \mathrm{ml})$} \\
\hline $\begin{array}{l}\text { Aspergillus fumigatus } \\
\text { (RCMB 002008) }\end{array}$ & $17 \pm 0.23$ & $12 \pm 0.11$ \\
\hline $\begin{array}{l}\text { Penicillium expansum } \\
\text { (RCMB 001001) }\end{array}$ & $17 \pm 0.23$ & $11 \pm 0.11$ \\
\hline
\end{tabular}

\begin{tabular}{llc}
\hline Yeasts & \multicolumn{2}{l}{ Ketoconazole $\mathbf{( 1 0 0 ~} \mathbf{~ m g} / \mathbf{m l})$} \\
\hline $\begin{array}{l}\text { Candida albicans (RCMB 005003) } \\
\text { (ATCC 10231) }\end{array}$ & $20 \pm 0.02$ & $12 \pm 0.18$ \\
$\begin{array}{l}\text { Cryptococcus neoformans } \\
\text { (RCMB 0049001) }\end{array}$ & $25 \pm 0.05$ & $19 \pm 0.13$ \\
\hline
\end{tabular}

*NA: No activity; **Positive control for fungi: Ketoconazole (MIC) $100 \mathrm{mg} / \mathrm{ml}$. Positive control for bacteria: Gentamicin (MIC) 4 mg/ml; RCMB: Regional Center for Mycology and Biotechnology in Cairo, Egypt; ATCC: American Type Culture Collection 
function, inhibition of energy metabolism, inhibition of the attachment and biofilm formation, inhibition of the porin on the cell membrane, and inhibition of a number of bacterial virulence factors, including quorum sensing signal receptors, enzymes, and toxins and alteration of the membrane permeability and attenuation of the pathogenicity [26]. From the previous data obtained, we can say that the methanolic extract of the plant has a good antimicrobial activity for both selected strains of bacteria and fungi but lower than reference used drugs.

\section{Antioxidant activity}

Oxygen is involved in chemical reactions in the body, in which electrons are shifted around it. To generate energy, our cells remove electrons from sugars, fatty acids, and amino acids and add them to other molecules, especially oxygen. This creates highly reactive, unstable particles known as free radicals, which combine quickly with other elements. Free radicals considered highly reactive compounds formed when an atom or a molecule gains or loses an electron and causes harmful for cells, dangerous to the body and damages all major components of cells, including DNA, proteins, and cell membranes. It may lead to aging and chronic illnesses, such as heart disease, cancer, Alzheimer's, and other health conditions $[27,28]$.

DPPH scavenging method was utilized to evaluate the antioxidant activity of the methanolic extract of $F$. viridis aerial parts using ascorbic acid as a reference standard, and the results are summarized in Table 3. Methanol extract at concentrations $(25,50,100,200,400,800,1200$, and $3200 \mu \mathrm{l}$ ) exhibited antioxidant capacity (51.52-92.43\%) with The $\mathrm{IC}_{50}$ 32.24. The outlined data recorded in Table 3 showed moderate antioxidant activity of the methanolic extract of $F$. viridis with $\mathrm{IC}_{50} 32.24$ as compared to ascorbic acid activity with $\mathrm{IC}_{50} 14.20$. The relative activity of the methanol extract may be due to a sufficient amount of flavonoid and phenolic acids besides other chemical constituents present in the methanolic extract as (Vitamin C, polyphenols, terpenoids, and

Table 3: Antioxidant activity of methanolic extract of Forsskaolea viridis compared to ascorbic acid

\begin{tabular}{llll}
\hline \multicolumn{2}{l}{ DPPH scavenging $\%$} & & \\
\hline Conc. $(\mu \mathrm{g} / \mathrm{ml})$ & Methanol extract & Conc. $(\boldsymbol{\mu g} / \mathbf{m l})$ & Ascorbic acid \\
\hline 0 & 0 & 0 & 0 \\
25 & $41.52 \pm 0.08$ & 5 & $11.78 \pm 0.02$ \\
50 & $57.25 \pm 0.09$ & 10 & $17.98 \pm 0.04$ \\
100 & $63.74 \pm 0.14$ & 15 & $54.86 \pm 0.09$ \\
200 & $72.32 \pm 0.16$ & 20 & $70.94 \pm 0.07$ \\
400 & $81.21 \pm 0.07$ & 25 & $77.41 \pm 0.10$ \\
800 & $89.84 \pm 0.23$ & 30 & $80.65 \pm 0.10$ \\
1600 & $90.89 \pm 0.11$ & 35 & $87.53 \pm 0.08$ \\
3200 & $92.43 \pm 0.15$ & 40 & $92.48 \pm 0.03$ \\
IC $_{50}$ & 32.24 & $\mathrm{IC}_{50}$ & 14.20 \\
\hline
\end{tabular}

DPPH: 2,2-Diphenyl-1-picrylhydrazyl hydrate saponins) [6,29]. These phytoconstituents characterized by their powerful antioxidant properties, where they might be responsible for the antioxidant activity of $\mathrm{MeOH}$ extract through breakdown the free radical reaction and neutralize the unpaired electron with donating electrons to eliminate the unpaired condition of the radical [30]. The flavonoid and phenolic contents in the methanolic extract may directly react with the reactive radicals and destroy them. Furthermore, they may decrease the cellular level of free radicals either by inhibiting the activities or expressions of free radical generating enzymes [31,32]. The antioxidant activity of isolated flavonoids depends on their chemical configuration, the arrangement of the functional group in the aromatic ring, substitutions, and the total number of hydroxyl group significantly influence several mechanisms of antioxidant activity such as radical scavenging and metal ion chelation ability [33,34]. Furthermore, the B ring hydroxyl configuration is the most significant determinant of scavenging of reactive oxygen species and reactive nitrogen species because it donates hydrogen and an electron to hydroxyl, peroxyl, and peroxynitrite radicals, stabilizing them and giving rise to a relatively stable flavonoids radical [35]. The presence of unsaturated 2-3 bond in conjugation with a 4-oxo function is more potent antioxidants where the conjugation between the A and B rings allows a resonance effect of the aromatic nucleus that provides stability to the flavonoid radical so it increases its upregulation or protection of antioxidant defenses [36]. The outlined results indicated that most of the isolated compounds from the methanolic extract characterized by flavonoids chemical skeleton which reflected their biological activity as an antioxidant, antimicrobial, and antitumor activity.

\section{Cytotoxic activity}

In the past decades, natural compounds have achieved remarkable achievements in the treatment of tumors through chemotherapy. This inspired scientists to continuously explore anticancer agents from natural compounds. Cancer is considered as a genetic illness caused by mutated genes. It is implicated in cell proliferation and cell death. DNA damage may lead to cell death. The most genetic abnormalities in human cancer cells are based on p53-mutated proteins which responsible genes to proliferate the cells. The flavonoid compounds act on the expression of $\mathrm{p} 53$ proteins which may lead to arrest cancer cells in the $G_{2}$ and mobile phases of the cell cycle. Tyrosine kinases are proteins which considered as growth factor signals for the nucleus. The expression of the protein is involved in oncogenesis. The flavonoid compounds can inhibit tyrosine kinase activity, controlled in inhibition of cancer cell growth, arrest cell cycle in proliferating lymphoid cells and inhibit heat shock proteins in several malignant cell lines, comprising leukemia, colon cancer, hepatic, and breast cancer [37].

Our study concerned with in vitro studies of isolated compounds in the methanolic extract of $F$. viridis aerial parts against Caco- 2 and MCF-7 and HEPG-2. The findings recorded in Table 4 revealed that the methanolic extract exhibited potent antitumor activity against (HEPG-2) with $\mathrm{IC}_{50} 49.72 \mu \mathrm{g} / \mathrm{ml}$ with effective about $80.7 \%$, weak activity against colon

Table 4: Antitumor activity of the methanolic extract of Forsskaolea viridis aerial parts against breast (MCF-7), colon (Caco-2), hepatic (HEPG-2), and normal (Vero) cell lines

\begin{tabular}{llll}
\hline Conc. $\times \mathbf{1 0} \mu \mathrm{g} / \mathbf{m l}$ & \multicolumn{2}{l}{ Viability $\%$ of methanol extract } & MCF-7 \\
\cline { 2 - 4 } & Vero & Caco-2 & $4.986 \pm 0.29$ \\
\hline 1000 & $4.629 \pm 0.07$ & $4.061 \pm 0.23$ & $5.643 \pm 0.45$ \\
500 & $5.820 \pm 0.05$ & $5.042 \pm 0.31$ & $7.086 \pm 0.36$ \\
250 & $9.259 \pm 0.12$ & $6.022 \pm 0.15$ & $10.498 \pm 0.24$ \\
125 & $10.052 \pm 0.15$ & $6.862 \pm 0.14$ & $18.766 \pm 0.13$ \\
62.50 & $22.619 \pm 0.09$ & $8.823 \pm 0.23$ & $28.346 \pm 0.11$ \\
31.25 & $37.566 \pm 0.02$ & $10.924 \pm 0.19$ & $59.317 \pm 0.09$ \\
15.62 & $72.486 \pm 0.11$ & $28.431 \pm 0.35$ & $97.900 \pm 0.06$ \\
7.81 & $94.708 \pm 0.13$ & $86.274 \pm 0.09$ & $3.691 \pm 0.33$ \\
3.90 & $97.421 \pm 0.04$ & $94.354 \pm 0.05$ & $3.375 \pm 0.42$ \\
1.53 & $100.00 \pm 0.00$ & $100.00 \pm 0.00$ & $4.641 \pm 0.20$ \\
$I_{50}$ & 258.07 & 154.41 & $8.4388 \pm 0.14$ \\
\hline
\end{tabular}


(Caco-2) with $\mathrm{IC}_{50} 154.41$ with effectively about $40.3 \%$, and no activity for breast carcinoma cell lines (MCF-7) with IC50 $224.19 \mu \mathrm{g} / \mathrm{ml}$ with effectively about $13.1 \%$ when compared to $\mathrm{IC}_{50} 258.07 \mu \mathrm{g} / \mathrm{ml}$ of the normal cell. The antitumor activity of the methanolic extract of both hepatic and colon carcinoma cell lines may be due to its isolated phytochemical constituents from phenolic and flavonoid components where, they exert their effects on cytochrome $\mathrm{P}_{450}$ to inhibit the activities of certain $\mathrm{P}_{450}$ isoenzymes, inhibit DNA damaging, mutagenic signaling, cell proliferation, and proto-oncogenes, inhibit of pro-oxidant enzymes which are responsible for the production of a number of procarcinogens and help in the production of metabolizing enzymes such as glutathioneS-transferase, quinone reductase, and uridine 5-diphospho-glucuronyl transferase by which carcinogens are detoxified and thus eliminated from the body [38,39].

\section{CONCLUSION}

The plant phytochemical constituents act the basics of folkloric medicine, where the medicinal plants are rich sources of a wide variety of chemical compounds and have been used as a major constituent of most indigenous medicines for a variety of diseases. The present study resulted in the characterization of seven pure compounds from the methanolic extract of $F$. viridis aerial parts that have been characterized as rutin, lucenin-2, chlorogenic acid, isovitexin, hesperidin, hesperetin, and ellagic acid. Flavonoids and phenolic compounds play an important role in diseases treatment where, they have antioxidant, hepatoprotective, anticancer, anti-inflammatory, antiviral, antimicrobial, antipyretic, antispasmodic, antiseptic activity, used as liniment, cough remedy, cold and flu drug, diuretic, treatment of kidney and urinary tract infections, hematuria, prostatitis, cholera, stomach ailments, rheumatism, gout, bruises, and calculus. In the present study, the methanolic extract was evaluated for the exploration of their antimicrobial activity against certain Gram-negative and Gram-positive bacteria strains and fungi species, evaluation of the antioxidant and antitumor activity of the methanolic extract. The obtained result demonstrates that the isolated compounds possess a significant inhibitory effect against tested pathogens, moderate antioxidant, potent antitumor activity for hepatic carcinoma cell line, and fair antitumor.

\section{AUTHORS' CONTRIBUTIONS}

Taha El Bassossy author for this publication, research scholar, desert research center, Cairo, Egypt (DRC), has carried out all the above chemical studies, i.e., isolation, purification, and identification of compounds at Phytochemistry Laboratory of Medicinal and Aromatic Plants Department, DRC under the guidance and contributions of Dr. Fatma Aly Ahmed, professor of phytochemistry, DRC who summarized, edited, and explained the discussion of the obtained data.

\section{CONFLICTS OF INTEREST}

The authors declare that they have no conflicts of interest.

\section{AUTHORS FUNDING}

Not applicable.

\section{REFERENCES}

1. Changkyun K, Tao D, Mark C, Dai-Gui Z, Ze-Long N, Hang S. Generic phylogeny and character evolution in Urticeae (Urticaceae) inferred from nuclear and plastid DNA regions. Taxon 2015;64:65-78.

2. Alfarhan AH, Al-Turk TA, Basahy AY. Flora of Jizan Region. Final Report. Vol. 1. King Abdulaziz City for Science and Technology; 2005.

3. Darias V, Bravo L, Barquin E, Martin Herrera D, Fraile C. Contribution to the ethnopharmacological study of the Canary Islands. J Ethnopharmacol 1986;15:169-93.

4. Darias V, Martín-Herrera D, Abdala S, Fuente D. Plants used in urinary pathologies in the Canary Islands. Pharm Biol 2001;39:170-80.

5. GBIF Secretariat: GBIF Backbone Taxonomy. Available from: http:// www.gbif.org/species/4101865. [Last accessed on 2016 Jun 09].

6. Ahmed FA, El-Mesallamy AM, El-Bassossy TA. Phytochemical analysis and biological evaluation of Forsskaolea viridis aerial parts.
Acta Pol Pharm 2019;76:815-23.

7. CLSI, Method for Antifungal Disk Diffusion Susceptibility Testing of Yeasts, Approved Guideline. CLSI Document M44-A. CLSI, 940 West Valley Road, Suite 1400, Wayne, Pennsylvania 19087-1898, USA; 2004.

8. CLSI, Performance Standards for Antimicrobial Disk Susceptibility Tests, Approved Standard, $7^{\text {th }}$ ed., CLSI document M02-A11. Clinical and Laboratory Standards Institute, 950 West Valley Road, Suite 2500, Wayne, Pennsylvania 19087, USA; 2012.

9. Letelier ME, Molina-Berríos A, Cortés-Troncoso J, Jara-Sandoval J, Holst M, Palma K, et al. DPPH and oxygen free radicals as pro-oxidant of biomolecules. Toxicol In vitro 2008;22:279-86.

10. Joyeux M, Lobstein A, Anton R, Mortier F. Comparative antilipoperoxidant, antinecrotic and scavenging properties of terpenes and biflavones from Ginkgo and some flavonoids. Planta Med 1995;61:126-9.

11. Viturro C, Molina A, Schmeda-Hirschmann G. Free radical scavengers from Mutisia friesiana (Asteraceae) and Sanicula graveolens (Apiaceae). Phytother Res 1999;13:422-4.

12. Mosmann T. Rapid colorimetric assay for cellular growth and survival: Application to proliferation and cytotoxicity assays. J Immunol Methods 1983;65:55-63.

13. Wei XH, Yang SJ, Liang N, Hu DY, Jin LH, Xue W, et al. Chemical constituents of Caesalpinia decapetala (Roth) Alston. Molecules 2013;18:1325-36.

14. Erel SB, Karaalp C, Bedir E, Kaehlig H, Glasl S, Khan S, et al. Secondary metabolites of Centaurea calolepis and evaluation of cnicin for anti-inflammatory, antioxidant, and cytotoxic activities. Pharm Biol 2011;49:840-9.

15. Berregi I, Ignacio JS, Campoa G, Ignacio JM, Aizpurua JM. Quantitation determination of chlorogenic acid in cider apple juices by ${ }^{1} \mathrm{H}$ NMR spectrometry. Anal Chim Acta 2003;486:269-74.

16. Lee JH, Park KH, Lee MH, Kim HT, Seo WD, Kim JY, et al. Identification, characterisation, and quantification of phenolic compounds in the antioxidant activity-containing fraction from the seeds of Korean perilla (Perilla frutescens) cultivars. Food Chem 2013; $136: 843-52$

17. Mabry TJ, Markham KR, Thomas MB. The Systematic Identification of Flavonoids. Berlin: Springer-Verlag; 1970.

18. Luzzatto T, Golan A, Yishay M, Bilkis I, Ben-Ari J, Yedidia I. Priming of antimicrobial phenolics during induced resistance response towards Pectobacterium carotovorum in the ornamental monocot calla lily. J Agric Food Chem 2007;55:10315-22.

19. Han S, Mok Y, Kim H, Lee J, Lee D, Lee Y. Determination of hesperidin in mixed tea by HPLC. CNU J Agric Sci 2011;38:295-9.

20. Nawwar MA, Hussein SA, Merfort I. NMR spectral analysis of polyphenols from Punica granatum. Phytochemistry 1994;36:793-8.

21. Brown DG, Lister T, May-Dracka TL. New natural products as new leads for antibacterial drug discovery. Bioorg Med Chem Lett 2014;24:413-8.

22. Newman DJ, Cragg GM. Natural products as sources of new drugs over the 30 years from 1981 to 2010. J Nat Prod 2012;75:311-35.

23. Menichetti F. Current and emerging serious Gram-positive infections. Clin Microbiol Infect 2005;11 Suppl 3:22-8.

24. Savitha T, Arivukkarasu R. Determination of phytocompounds from Terminalia chebula retz by HPTLC desnsitometric methods. Int J Pharm Pharm Sci 2014;6:516-20.

25. Dzoyem JP, Hamamoto H, Ngameni B, Ngadjui BT, Sekimizu K. Antimicrobial action mechanism of flavonoids from Dorstenia species. Drug Discov Ther 2013;7:66-72.

26. Cushnie TP, Lamb AJ. Recent advances in understanding the antibacterial properties of flavonoids. Int $\mathrm{J}$ Antimicrob Agents 2011:38:99-107.

27. Diplock AT, Charleux JL, Crozier-Willi G, Kok FJ, Rice-Evans C, Roberfroid $\mathrm{M}$, et al. Functional food science and defence against reactive oxidative species. Br J Nutr 1998;80 Suppl 1:S77-112.

28. Valko M, Leibfritz D, Moncol J, Cronin MT, Mazur M, Telser J. Free radicals and antioxidants in normal physiological functions and human disease. Int J Biochem Cell Biol 2007;39:44-84.

29. El-Mesallamy AM, Ahmed FA, El-Bassossy TA. Chemical Investigation of flavonoids, phenolic acids and Vitamins compositions of Forsskaolea viridis aerial parts. Egypt J Chem 2019;62:1815-22.

30. Viswanathswamy AH, Yadala P. In vitro antioxidant and cytotoxic activity of rutin and piperine and their synergisitic effect. Int $\mathrm{J}$ Pharm Pharm Sci 2016;8:78-82.

31. Lü JM, Lin PH, Yao Q, Chen C. Chemical and molecular mechanisms of antioxidants: Experimental approaches and model systems. J Cell 
Mol Med 2010;14:840-60

32. Wang X, Ouyang YY, Liu J, Zhao G. Flavonoid intake and risk of CVD: A systematic review and meta-analysis of prospective cohort studies. $\mathrm{Br}$ J Nutr 2014;111:1-11.

33. Heim KE, Tagliaferro AR, Bobilya DJ. Flavonoid antioxidants: Chemistry, metabolism and structure-activity relationships. J Nutr Biochem 2002;13:572-84.

34. Pandey AK, Mishra AK, Mishra A. Antifungal and antioxidative potential of oil and extracts derived from leaves of Indian spice plant Cinnamomum tamala. Cell Mol Biol (Noisy-le-grand) 2012;58:142-7.

35. Cao G, Sofic E, Prior RL. Antioxidant and prooxidant behavior of flavonoids: Structure-activity relationships. Free Radic Biol Med
1997;22:749-60.

36. Rice-Evans CA, Miller NJ, Paganga G. Structure-antioxidant activity relationships of flavonoids and phenolic acids. Free Radic Biol Med 1996;20:933-56.

37. Duthie GG, Duthie SJ, Kyle JA. Plant polyphenols in cancer and heart disease: Implications as nutritional antioxidants. Nutr Res Rev 2000;13:79-106.

38. Ren W, Qiao Z, Wang H, Zhu L, Zhang L. Flavonoids: Promising anticancer agents. Med Res Rev 2003;23:519-34.

39. Panche AN, Diwan AD, Chandra SR. Flavonoids: An overview. J Nutr Sci 2016;5:e47. 